\title{
The Main Factors of Survival of the Royalty in England from Elisabeth I to the Present
}

\author{
Be. Mehounou Mathias Adande \\ Be. Adounsiba Gerard \\ Dr. Moustapha Franck
}

*Corresponding Author: Be. Mehounou Mathias Adandé

\begin{abstract}
The purpose of this article is to study first, the factors which contribute to the unwavering attachment of the English to their monarchs, and on the other hand, the factors of their survival till now. Indeed, the survival of the monarchy in Britain would result, not only from extrinsic historic factors, sociocultural and religious, but above all on intrinsic related to its ability to changes and its adaptation to the great social upheavals such as French, Russian, and German Revolutions and the two World Wars. In any event, if it is strong, absolute, moderate or figurative, United Kingdom has always enjoyed and continues to enjoy even today an almost religious consideration because of the secular myths which enclose the royalty. All this because British people are conservative people strongly attached to their monarchy and refractory to great social upheavals.
\end{abstract}

Keywords: Monarchy-survival- historical factors- religious considerations-attachment

\section{INTRODUCTION}

Elisabethan and Victorian eras were periods of remarkable magnitude. Such magnificence was clearly visible in all areas of national life. These periods of relative stability have seen the Kingdom develop remarkably and integrate itself into the concert of the great European nations under Elisabeth I, before to rising in a inexorable way to the position of first power and largest global empire under Victoria. Under the enlightened guidance of their sovereigns, Elisabethans and Victorians have resolutely engaged themselves on the way toward a sustainable progress. Galvanised by the harmonious development of their country, they came to see themselves as a breed apart. They identified with their Queens and considered themselves as a breed chosen by God to lead civilisation. To better understand this unwavering attachment of the English to their monarchs, one should consider the central role played by the monarchy for several centuries in fostering social justice within the nation.

If during its long evolution, the monarchy has had mixed fortunes; it has also been able to maintain, adapt and establish itself as an unavoidable necessity by mutating continually based on the circumstances. From its mythical character with what it embodies it is a solid cement for national unity and thus has a considerable impact on the popular mentality ${ }^{1}$.

This impact of the monarchy on the British people comes from several factors of which the most important is undoubtedly the nature of the coronation.

Indeed, by being crowned according to the rites of their ancestor Edgar (959-975), grand-nephew of King Alfred and the first recognised king of England, not only monarchs continue an old centurieslong tradition of the English monarchy, but above all this gives them a sacred character.

\section{1- FUNDAMENTAL FACTORS OF THE SURVIVAL OF THE BRITISH MONARCHY}

The monarchy is a unique British institution that has enjoyed almost uninterrupted reverence for centuries. This mark of almost eternal respect is the result of the combination of a set of factors that is made of the royal power, its divine function and the perception of the monarch as a fantastic, mythical, and legitimate being representative of God on earth. Such a deification of the royal power,

${ }^{1}$ T. Bindoff et al. Dir., Elizabethan Government and Society, London : 1961, p. 123 
strongly supported by sovereigns and sycophants of power, is largely reflected in the literature throughout centuries. For example, in Kynge John (1519) of John Bale, a dramaturgic piece written in old English, the king is repeatedly described as the "anointed" who is delegated by God to ensure the country's government and the true religion. The interpreter of this work claimed that the first act does not say anything else and this statement is actually a profession of monarchist faith conform to the catechism of the Tudors and it clearly shows the worship and the full respect due to kings and the obedience that is required:

For, in his own realm, a king is judge over all by God's appointment; and none may him judge again but the Lord Himself: in this the sculpture is plaine. He that condemnth a king, condemnth God without doubt; he that harmth a king, to harm God he goes about. He that the prince resisteth, doth damn God's ordinance; and resisteth God in withdrawing his affiance. All subjets offending are under the king's judgment: a king is reserved to the Lord omnipotent. He is a minister immediate under God, of his righteousness to execute the rod. ${ }^{2}$

Therefore, it would be wrong to think that the English vow to monarchy and aristocracy was by chance. On the contrary, it was the result of a cleverly orchestrated and conducted scheme to inevitably lead to the mythologising of the noble, in general, and the most noble of the nobles the monarch, in particular. This myth which is built around a number of physical, intellectual, and moral properties, made of the monarch as a "sacred" being, noble exceptional men, exemplary and inaccessible natural guides, their pure blood of Aryan as we will see in this part.

My objective in this part is basically to show the critical, historical, social, cultural, religious, and political factors who have enabled the monarchy to ink itself in the popular mentality, to compose itself as an essential entity and the follow the major changes that shook through the centuries the European continent and even the world. My goal is ultimately to try to point out key elements that have, directly or indirectly, contributed to the survival of the English monarchy to the big revolutions and the World Wars.

\subsection{The Pillars of Social Stability in Britain}

The England of today gives a lot of observers an image of a pictured, exploded, devoid society of landmarks and an impression of chaos, or even of cacophony. This is especially due to the transformation of the social environment, the breakdown of old relationships of friendship and family, the inability of the masters to think about the youth, the promiscuity of the estates, the sometimes desperate search of contacts and distinction, the development of the leisure activities, holidays, stays abroad, which contribute mightily to reorient the mind. Such a situation is also due to the professional and social mobility that plays against the respect for the rules and the emergence of new lifestyles through books, records, newspapers, and audiovisual means ${ }^{3}$.

However, it should be noted that it was not always like this. A panoramic view of the history of England allows one to see clearly that old England was characterised by the rigidity of frames, of traditions and by conformism. All this, patiently, developed over time, building and maintaining the social and national consensus by inserting it like in a tight corset. Indeed, protected by its insular position, hiding at the unwanted or non desire foreign incursion, England has lived between the 16th century and the 19th century a multi-secular stability: a stability of its social structure, and its political institutions. No doubt the word "stability" must be understood in the sense of "the ability of an entity to regain its normal so-called initial value whenever it comes to be temporarily or accidentally discarded $^{4}$. In fact, apart from the exception of the of 1688 and 1649 revolutions, England has evolved very dynamically between the Elisabethan and Victorian era without ever questioning fundamentally its social structure.

\footnotetext{
${ }^{2}$ Cited by William A. Armstrong, Elizabethan History Plays, London: ed. The World Classics, 1965, p. 77.

${ }^{3}$ John Pearson, op. cit., pp. 7-8

${ }^{4}$ John Pearson, op. cit., pp. 7-8
} 


\subsection{English Conception of the Society}

One of the most important pillars of the survival of the monarchy is, with no doubt, the quasi - special conception that the English had of the notions of order, hierarchy, obedience, respect, and chaos. This model that had strongly prevailed throughout the 16th century remained vivid in the 19th century and survived even until today even if its impact has diminished along the way.

The Elisabethan conceived of society as an entity based entirely on an immutable hierarchy. To better understand this attitude, It should be better to analyse the psychology that supports it. Indeed, although the optimism and exuberance were the basic characteristics of age, we cannot be denied the marked presence of anxiety, ambivalence and conflict. This situation was due to several factors. First, if the double impact of humanism and the reformation ought to promote individual awareness and the rise of individualism, social structures, family, Church, State on the one hand, it forces people to define it themselves, even through several social roles. On the other hand, the patriarchal ideology established the hierarchy of genders and the subordination of the woman to the man by setting the feminine ideal as chaste, silent, and obedient. This same ideology was faced with the difficult problem of a woman at the top, on the throne. Finally, if the Elisabethans exalted social status and order, natural and social hierarchy, and great human beings, they were confronted with radical social tensions caused by the depletion of the aristocracy, the growing power of the merchants' class in the cities.

In addition, despite her political finesse, Elisabeth was threatened fronts throughout her reign on several front. On the religious front, the Elisabethans compromise was deemed too protestant by Catholics, and not enough protestant by the Puritans whose number keeps increasing. On the domestic front, the claim to the throne of her cousin Marie Stuart, Queen of the Scots, continued to worry her, and she couldn't get rid of this even after the execution of Marie Stuart by the Privy Council, thus creating a dangerous case of regicide. On the international front, the danger of the Spanish invasion was always present in the mind of the English even if after the defeat of the "invincible Armanda" this fear was somewhat mitigated on the Irish front, things went from bad to worse and ended by the disastrous expedition of Essex in 1599. Equally, Elisabeth had no heirs, and the succession to the throne of England was a constant source of concern to her subjects who feared a possible return of Catholicism and a rivalry that would lead to a civil war ${ }^{5}$.

The fear of the civil war, the disruption of the order and the return to the chaos that England had known before the advent of Tudors and at the time of the war of Roses dominate people's mind at the time. Thus, even if there were revolts against the social upper class or against the revolt clergy. This should not be considered as the tip of the iceberg of the latent discontent. In both cases, this protestations were caused by the disregard of social and religious principles understood and accepted by all. People have accepted the Christian revelation and therefore they protest whenever ministers of Christ in fringe or violate their priesthood. They have accepted the social hierarchy under God, and they protest when the nobles' obligations were flouted. The peer plans included on the one hand, the macrocosm and the body of policies by which the King or the Queen, for example, was assimilated to the sun and on the other hand, the political body and microcosm, by which the Commonwealth was treated as the human body which could not operate without the harmony between all parties. The cosmic dance had similar implications with hierarchies, land and the cosmos moving in perfect order. Reversing this order will mean returning to the universes primitive chaos. For Elisabethans, the principle of the anything unity accompanied the idea of order because the order enjoyed, and the perfection of the existing hierarchy was indisputable: neither nature could exist without the hierarchical order established by God, nor the society could exist without laws made by men inspired by reassuring principles offered by nature. An analysis of the theories of that time shows that Elisabethan England, in its political thought remained deeply rooted in metaphysics of faith burning as shown in this homily, which claimed to exalt the happiness of man in society but celebrates the organic perfection of the whole group. It focused on the fact that the social position of the individual must not be questioned but rather integrated in a hierarchy which is sanctified by God's will, the place

${ }^{5}$ A.Nicoll, p; cit,p.100 
of harmonious relations between the various components. Therefore, as wrote Hart:" It defines such politico-religious doctrines as the kings, non-resistance, passive, obedience, and the wickedness of rebellion ${ }^{6 "}$

\subsection{Social Hierarchy and Deference in Britain}

The social hierarchisation and deference are undoubtedly primordial factors of the survival of the monarchy in England. English society is one of the most hierarchical and more stable in the world. This is due to several factors which we have already mentioned. It is a question of the special design that the English have developed the notions of order, of social status and great human beings. All this enables them to establish a social hierarchisation which is almost permanent. However, the life of any society is a dynamic process and it would be wrong even illogically to support that the stratification of the English society has remained immutable from the $16^{\text {th }}$ century to today. Despite the characteristics linked to its insularity, the English society, like those of the European continent, is a mobile society. Some of its social strata, in their natural dynamics, have merged and have become almost unnoticed. Four social classes have been presented by Harrington and Smith in the $16^{\text {th }}$ century of which it remained in the $20^{\text {th }}$ century, three according to Palerston's classification and two according to Karl Marx in its logical dialectic. However, this should be put in the perspective and social mobility and all the barriers that separated the high classes to the low classes were almost waterproof and impenetrable.

In fact, crossing these social barriers has never been anything automatic, because this follows a number of requirements which are normative and duly predetermined.

To better understand the reasons for this consistent stability and the quasi immutability of the structures of the English society, it is absolutely essential to visit the philosophy that has underpinned this since the $16^{\text {th }}$ century. On a sign in Grafton Manor in Worcestershire dating from 1567, you can read the following inscription written in old English:

Plenti and grase bi in this place; Whyleeveri man is pleased in this degres there is both pease and uniti; Salamansaith there is none acorde when everi man woud be a lorde ${ }^{7}$

Basically, this inscription means there will never be peace and unity where every man wants to be a lord.

This although very lapidary embodies the fundamentals of the Elisabethan social philosophy which are order, hierarchy, obedience, and deference. Tudorian vision of society is quite conventional and even feudal that the management of the family unit is the faithful reflection of the relationship between political structures and allegiance in that the family is a hierarchy of men and women who know all their real space and duties. This vision is, in fact, the basis of the Elisabethan patriarcal system and also that of the Stuarts who have followed. It is also the necessary cement for the " deferent society " to the extent that the knowledge of its own social hierarchy is important as presented by Smith and Harrington.

What is amazing about England, is its ultra-conservatism and the near constancy of its social structure and the controversies they have continued to arouse from the 16th to the 19th century. Indeed, more than two centuries after Elisabethan era, the debate raised by social stratification seemed to always be on the agenda. Victorian society presented in its various social strata the same components as those of the Elisabethan society and their quantification always attract the same controversy. Most contradictory, it supported the views or antagonisms. For some there were only two classes; for others it's a three-class system; some went even five or more. Some simply denied the possibility to define classes' lack of internal homogeneity.

\footnotetext{
${ }^{6}$ A Alfred Hart, Shakespeare and the Homilies and other pieces of Elisabethan drama, Melbourne : M.U.P., 1938, p. 45.

${ }^{7}$ Cited by Roland Marx, L'Angleterre des révolutions. Courants et Mouvements, Paris : Librairie Armand Colin, 1971, p.288.
} 
Consequently, the same questions, whether it was necessary to talk of unipolar, bipolar, and tripolar society (or even multi ) raised in the 16th century still poses acute difficulties. One of the fiercest defenders of the binary stratification of English society is probably Karl Marx who argues that:

In all countries Britain was where the despotism of capital and labor slavery had reached their greatest development; the process of disappearance of the middle classes leaving more facing the millionaire head of whole industrial armies and wages - slaves forced to live from day to day [... Jin Britain have established a complete divorce of property and labor. In no other country the war between the two classes that constitute modern society has made such colossal proportions or characters as clear and as tangible $e^{8}$.

The dualistic theory of Karl Marx was undeniably inscribed in a long tradition developed and maintained by precursors of socialism as Hall, representatives of social Toryism as Disraeli, and the majority of Chartists themselves heirs of the Jacobin language Cobbett. They have reduced all society into two classes: the rich and the poor, as in the famous thesis of Disraeli, or masters and slaves as Cobbett denounced with vehemence.

However, this dualistic scheme born out of the inflexible dialectic of property and wages is swept with a backhand by Sir John Temple Palmerston, prime minister between 1855-1858 and 1859-1865. In contrast to Marx and other dualist theorists, Palmerston has developed a tripolar concept of society which is considered as an assembly of mobile and free components. He presented a singularly optimistic theory based on the dynamics of a triangular (aristocratic patriarchy, bourgeois elite and the lower classes) and open society (everyone is free and only depends on his own will). As such he writes:

The happy balance which characterises England holds the combination as a quite unique hierarchy of recognised and accepted and a sometimes effective and sometimes social mobility potential. Indeed, in a constitutional monarchy it must be a rank of aristocracy - the nobility and aristocracy of wealth - the bourgeoisie. Below is the mass of the people. Here anyone can aspire to rise up at the highest level provided he spends the talents, energy, perseverance and good conduct necessary because wealth is to some extent in everyone. Therefore; all ambitions are allowed ${ }^{9}$.

In fact, Palmerston has merely followed the tradition of British economic thought already largely developed and maintained by classical economists such as Sir James Stuart, John Miller and especially Adam Smith. These are indeed themselves the precursors of the tripolar conception of society by launching the landlords triad manufacturers and workers (laborers), as they were the first to define a class by the economic structure - mode of production and income.

\subsection{Xenophobic Nationalism}

If England has remained relatively stable for centuries and this is largely due to its highly developed nationalism and its insularity. These two significant factors have contributed in many way to the preservation of social cohesion and enabled repeatedly England to face triumphantly his many enemies on the continent. Under Elisabeth I, xenophobia which has sometimes took form of racism was one of the consequences of English nationalism. This chauvinism struck above all Spain, but also extended to Italy and France without sparing Ireland and Scotland. Both internal and external events tended to accentuate this hostility. Behind this xenophobia hides the fear of foreign invasion that remained for much of the reign of Elisabeth one of the main concerns of the government.

Thus, because of the surge of nationalism on the continent there was such a tightening around the person of the queen, so she became the symbol of English nationalism. The spirit of nationalism,

\footnotetext{
${ }^{8}$ Karl Marx cited by François Bedarida, cit, p. 25

${ }^{9}$ Ibid , cit, p. 28
} 
patriotism, and chauvinism exacerbated in times of conflict with rival political powers have played a decisive role in the consolidation of social national cohesion. This because in their quest for unity, the British found themselves under the obligation to rally around Elisabeth who had well become the icon of national unity and the guarantor of the essential virtues of the race.

It is undoubtedly this chauvinistic behavior of the vast majority of English which has led them to give utmost importance to order in the Church and in the State and to see Elisabeth, in his person and in his policy, as the symbol of social cohesion. And besides the survival of the Queen for such a long period in itself was sufficient to allow the national consciousness to build solid foundations in all strata of the social hierarchy.

Under Victoria, this English nationalism took on a special dimension. This is undoubtedly due to the fact that from 1851, England was unquestionably becoming the leading world power. In any case, one cannot deny the fundamental role that nationalism play in the consolidation of the English nation, as an antidote to the many attempts of upheaval, and social disruption as a solidarity bloc against foreign aggression, as cement firmly linking all social strata in a fortress an almost impregnable citadel embodied the Queen. This is even more true that this is chauvinism which probably served as part of reunion and national reconciliation where most of the nation was comforted and bridled while striving to minimise abroad, this another man ruled by English society. It is, of course, the island spirit which was the basis of this self-absorption of English. It is their insularity that has always provided a double sense of security and superiority. In their island, they felt like an impregnable fortress as protected by the sea which at the same time gave them easy access to all points of the globe.

\section{The MYTh OF THE RULing ClaSSES}

The duty of care and the concealment of power are two other royal qualities which obviously can help explain the mythic dimension of Queen Elisabeth. In most of the great mythologies the mythical hero not only experiences a very difficult childhood, but must also go through initiation rites that allow him to consolidate his experience and to accomplish the feats that will underpin later the mythologising of the person and Elisabeth like other legendary characters was no exception to the rule. Already as a very young Princess Elisabeth went through the hardships that have failed repeatedly to cost her life. These series of events that can be described as initiatory have given her a hidden power and a caution that allowed her not only to survive multiple threats, but also to reign successfully once on the throne.

The image of the mythical character can be true or false. The essential is not there because everyone knows that a misconception can deeply upset than a true idea. This image as it imposes on society is a dazzling and impressive image. It serves to support the dreams and daring without which society will be able to exceed itself or leave the paths set by years of conventional routine. Here, they ask the model, sublimated and exalted, one of order, image and continuity. It appears then as an allowing necessity to develop an existing model. True or false, it enters the minds where possible extends and changes the face of the truth acquired and imposed by society.

The possession of the virtues assures the monarch mythical grandeur and gives him the privilege of leaving in the heart of his people an ideal image. For the exaltation of the popular imagination feeds mainly of mythical images and indeed the monarch derives its prestige under his personal qualities however eminent they may be that the values that attach to his royal function: around the idea of the monarchy crystallize many moral values affective, aesthetic. Thus the doctrine of the divine right is to confuse all issues in a bid to duty obedience based on admiration on the belief of the superiority of the monarch on glare it causes.

\subsection{The Sacred Royal Power}

In his work The Aryan Myth: Essay on the causes of racism and nationalism, Leon Poliakov tries to show that the study of the social sciences proves explicitly that there is no normal society - that is socially, politically, and culturally viable - with claims to a genealogy and a mythical origin. Therefore, there is no culture, so archaic it may be, which is to be built in this way a spontaneous anthropology. For members of any human group can claim to be the descendants of a god, a hero, or even a mythical animal ${ }^{10}$.

\footnotetext{
${ }^{10}$ Léon Poliakov, Le Mythe Aryen, Essai sur les sources du racisme et des nationalismes, Paris, 1292, p. 19
} 
Therefore, the mythical genealogy research appears, obviously, as the first form of historical reflection, and in this respect, at least, it becomes easy to advance that there is no society without history because as human history seems logically primed with human evolution and have formalised with socialisation ${ }^{11}$.

Thus, explain the universality of references to the common ancestor and myths of origins, as well as illuminated their functions, which is to explain the fundamentals of the race and often to justify the legitimacy, and nobility of the ruling and aristocratic families. Therefore, if one consider the evolution of the histories of humanity, it is as if when the development and differentiation of societies the rise of states and empires, the progress of socialisation, and knowledge, each nation had striven to use the forces expressed through myths of origin for purely nationalistic, and even xenophobic purposes. In this effort of particularisation, England is champion. Because it is an island and the islands have a reputation for being provisional vestiges of the past, and therefore the customs and traditions mostly forgotten on the continent. This is also why it is said that the islands have good memory.

It appears, then, clearly that the sacredness of royal power emanated partly from the sustained effort historians and theologians of royalty vigorously deployed to demonstrate the divine and mythical character of the royal power and this no doubt contributed greatly to the survival of the English monarchy. However, we must recognise that other no less important myths such as aristocratic myths have also played a key role in the survival of the monarchy in England as we shall see in the following section. Therefore, it would be difficult or impossible to deny the vital role aristocratic myths have played in the survival of the monarchy in England. The monarch as the noblest of the noblemen was supposed to embody more than any other person the virtues of her class through her physical appearance behavior and natural intellectual capacities. Also, she was supposed to embody other virtues considered more noble as we shall see in the following section.

\section{THE IMPACT OF THE ELISABETHAN MONARCHY}

The Elisabethan era was a particularly long time, probably one of the longest in English history: Elisabeth I reigned for forty five years from 1558 to 1603 . This long reign was undoubtedly a period of relative stability. Compared to the troubles of the times that preceded it - The Hundred Years War (1337-1453), the War of the Roses (1455-1485), the henrician Reforms (1532-1547), and of those periods that followed the Revolution of 1649 and the Glorious Revolution of 1688 the Elisabethan era might seem like a safe haven despite the cyclical rated revolts here and there such as Radolfi conspiracy in 1571, the Essex revolt of 1599 and 1600. This was without any doubt due in large part to the special design the Elisabethans had, the notion of social status and the position of the one who embodied the summit of the state.

There is one aspect of the mythical character of Queen Elisabeth who has had a lasting impact on his subjects, the compromise. Indeed, the compromise policy of "give and receive", of "live and let live" that she has adopted to solve the religious problem and that was extended to all levels of Elisabethan society. The English had mastered the lesson that they could be free by allowing others to be free, they could not spread their opinions by not listening carefully to those of others. This philosophy of hard-won tolerance was largely underpinned by the Christian belief in the sanctity of the individual. His goal was to make English religious men gentle, generous, humble, brave, tolerant and chivalrous $^{12}$. Its basic ideals were justice, forgiveness, charity.

Elisabethan institutions were designed to allow people to more easily achieve this idealism. In their midst, they could lead a Christian life without jeopardising human needs and without conflict between their conscience and circumstances; treat they neighbors with a sense of responsibility did not prevent a noble or a merchant to thrive. Therefore, it became natural for Elisabethan to live and work in a society where morality and tolerance existed. Even long after completely severed from her Catholic past, Britain still cherished the old ideal of a kingdom engaged in its duty to produce just men, who are gentle and tolerant. Besides, what was the best of Puritanism was the attempt to restore this ideal.

\footnotetext{
${ }^{11}$ Ibid, p. 63

${ }^{12}$ C. E. Eckersley and L.C.B. Seaman, Pattern of England, Book two, London: Longmans, Green and $\mathrm{C}^{\circ}$ Ltd, 1964,p. 120.
} 
This is largely supported by what the Queen Elisabeth herself has said: "I will never be constraint to do anything. I thank God, I am endued with such qualities that if I were turned out of the realm in my petticoat, I were able to live in any place in Christendom ${ }^{13}$.

This is the way that the Queen has ruled England and this mythical behavior has had a great impact on the people especially during the attempted invasion of the kingdom by Spain. Indeed, during these difficult periods, the English of all political and religious persuasions, have rallied around the Queen to defend their homeland. I have already mentioned that Elisabeth did not have any army to defend herself. She was strong and the need did not occur to her necessarity to have an army, or a police force. Rather it came from her ability to mobilise his subjects around the essential whenever the interest of the nation was at stake. In these difficult situations, her courage and composure always served to galvanise them. Supported by public opinion, she had taken hold of spiritual power through the myth surrounding her person.

\section{THE IMPACT OF THE VICTORIAN MONARCHY}

Queen Victoria was as Queen Elisabeth I, one of the most remarkable sovereigns of English history. Yet, they were born and grew up in completely different contexts. Indeed unlike Elisabeth who had a childhood marked by terrible trials that have failed repeatedly to cost her her life, Victoria lived in a serene environment under the cover and the strict supervision of her mother, her housekeeper of Baroness Lehzen, and later Duchess of Northumberland. Surrounded by members of the Whig party to which her father belonged and initiated to their principles by Viscount Melbourne, she had become perennial and natural and learned to put aside conflicts within the royal family.

Princess Victoria was raised in a strict simplicity next to his mother. Virtually separated from her father's family, she learned to see themselves as Coburg (his mother's family) rather than a member of the House of Hanover. Legend had it that until the age of twelve, she was not aware that she could accede to the throne of England; legend in which Victoria would plant some doubt.

When Victoria ascended to the throne at the death of her uncle William IV June 2, 1837, a fresh breath seemed to pass on the kingdom and the British people gave way to expressions of loving loyalty. The accession of a so young Queen aroused with many great hopes. The reason was simple, that is the prestige of the monarchy was the final blow it is being carried by the last three monarchs of the House of Hanover: George III was plagued by cyclical madness; George IV was a pretentious and insufferable, William IV was a semi stupid slob.

Immediately after chairing the Privy Council, Victoria decided to separate the bulk of people in her immediate environment. Accordingly, once she moved to Buckingham Palace, she confined her mother in a remote apartment of her own. The Duchess of Kent, her mother had so far hardly left her out of view, helping her in her toilet, accompanying her on her walks, attending his lessons and sleeping in the same room with her. Never the little princess had seemed to take offense to this cumbersome tenderness.

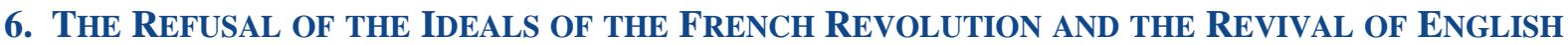 MONARCHY}

The period called the French Revolution, between 1789 and 1799, constitutes a considerable breach abolishing the monarchy, inventing new social relationships, and using a new political language in France. This upheaval does not represent only the tip of the revolutionary movements that occur in Europe and in North America at the same period, appealing to the reformers in these regions in more radical terms and lays the foundations for a new political culture. The violence which and which is expressed in a particularly strong way highlights the novation.

The French Revolution is alone an era in the history of Europe and the world, breaking the string of time, as contemporaries did not fail to observe it. Also its causes, its modalities and its consequences have been regularly the subject of passionate analyses. The brutality of the fighting and the magnitude

${ }^{13}$ Cited by Kate Aughterson, op. cit. p.102. 
of the civil wars and subsequent, institutional turnarounds have so marked consciences and memories that it is easy to understand the harshness of the debates in relation to about the mention these events.

A casual observer would have noticed little reaction in England. While the France took the Bastille, proclaimed human rights and established the basis of a new society, England was working to build its industry to consolidate, and then expand, its global trade very experienced at this time. Parliament lived in the routine without knowing any sensational event.

The Victorian era is thus defined as that of the reconciliation of the English between them, of the Crown and the people, of the international greatness, of peace. The word "Victorian" also applies to all aspects of morality and mentality, and qualifies the literature and the arts of the period. The time is sometimes seen artificially with a unit that is not known, but still basking in the legend of a British golden age, the last before the sufferings of the century of total war.

"Grandmother of Europe", Queen Victoria, in her later years contemplated an increasingly torn world. Small packed woman, always dressed in black, she abdicated nothing of her authority. She moved everything, expected reports and information on all, granted no authority to the Prince of Wales. His presence on the throne undoubtedly contributed to giving back to the monarchy its rightful place in English society, which allowed her to survive before crucial events like the two World Wars of 19141918 and 1939-1945.

\section{CONCLuSion}

By choosing the subject of this research, my purpose was to examine some critical or important factors that have contributed to the survival of the monarchy in Britain. At the end of this work, it appears clearly that if the English monarchy has managed to survive the social, political, economic, and major religious upheavals which have deeply shaken repeatedly the foundations of the kingdom in the wider context of Europe. This is because of the existence of not only supporting extrinsic factors, but also that of very favorable intrinsic factors. Indeed this centuries-old institution of monarchy certainly has an amazing ability to adapt and readjust which, undoubtedly, has helped the monarchy to preserve and perpetuate itself through the tribulations of history. It showed at crucial moments in history as was the case under Elisabeth I a period when the kingdom was under constant threats from foreign powers such as France and Spain; under George III the ideals of the French Revolution have threatened to undermine the social and political structures of the whole Continent; in Victorian times when the monarchy had lost all credibility because of the heinous actions of George IV; and under George V and George VI times when the two world wars have caused the fall of many almost all European monarchies.

Over the centuries, the British monarchy has resisted and survived all sorts of challenge and upheavals and has enjoyed expansion and glory thanks to its genius to adapt to circumstances both internal and external. However, as noted by the husband of the Queen Prince Philip in person, the survival of the monarchy is based ultimately on the approval of its subjects.

Furthermore, it would be absurd to propose a new institution devoided of traditional respect and of the religious consecration to replace out of nothing a constitutional king in nations whose history is monarchical. The nation is divided into parties with respective interests and the king remains outside of it all. His apparent distance from the party business away from hostilities and desecration helps keep his mysterious charm and allows him to meet both the affection and the leadership need of all parties to become the visible symbol of unity for the people, symbol that the people cannot certainly do without.

\section{REFERENCES}

[1] Armstrong, William A. Elisabethan History Plays, London: ed. The World Classics, 1965, p. 77.

[2] Arthur. Donald, Innes. England under the Tudors. A history of England, London: Methuen, 1911.

[3] Agulhon, Maurice. Les Quarante-huitards, Paris : Folio, 1992 (1975).

[4] Bacon, Francis. The History of the Reign of King-Henry the Seventh. Lodon, 1957

[5] Duchein, M . Elisabeth I d'Angletere, Paris : Fayard, 1992, p. 193.

[6] Dufour, Alain. Histoire politique et psychologie historique, Genève : ed. Droz, 1966. 
[7] Eckersley, C. E. and Seaman L.C.B. Pattern of England, Book two, London: Longmans, Green and C Ltd, 1964,p. 120.

[8] Hume, David. The Histoire of England, from the invasion of Julius Caesar, (1762) London: Macmillan, 2nd ed. 1959.

[9] Keith, Arthur. Nationality and Race, London: Robert Boyles Lectures, 1919.

[10] McCalman, Iain. Radical Underworld: Prophets, Revolutionaries and Pornographers in London, 17951840, Cambridge: Cambridge University Press, 1988.

[11] Pollard, Albert Frederick.. The Reign of Henry VII from Contemporary Sources, 3 vol., London: ed. Thompson, Royal Society of Literature, 1913.

[12] Santon, Kate et McKay. Atlas historique du monde, Londres : Parragon Books Ltd, 2006.

\section{AUTHORS' BIOGRAPHY}

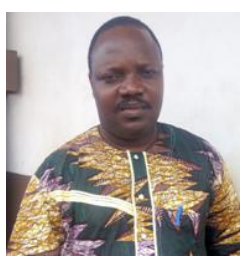

Mathias Adandé Mehounou, is Dr to be of University of Abomey Calavi. He is English teacher in Benin Secondary Schools. He also assists his professor to teach British Civilisation and Litterature at University of Abomey Calavi.

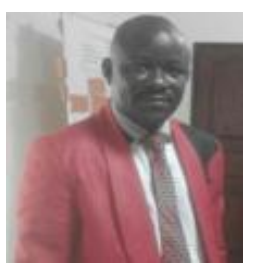

Gérard Adounsiba, is a Dr to be at the University of Abomey Calavi.He teachs English at Bénin Secondary schools. He also assists his professor to teach British Civilisation and Literature at University of Abomey Calavi.

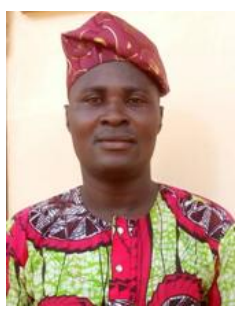

Dr Franck Moustapha, teachs British Civilisation and Literature at the University of Abomey Calavi. He also assists his professor at the University of Abomey Calavi.

Citation: Be. Mehounou, Mathias Adande et al. "The Main Factors of Survival of the Royalty in England from Elisabeth I to the Present." International Journal on Studies in English Language and Literature (IJSELL), vol 5, no. 9, 2017, pp. 11-20. doi:http://dx.doi.org/10.20431/2347-3134.0509002.

Copyright: () 2017 Authors. This is an open-access article distributed under the terms of the Creative Commons Attribution License, which permits unrestricted use, distribution, and reproduction in any medium, provided the original author and source are credited. 